\title{
An appraisal of the practice of corporate diversification in selected Nigerian banks
}

\author{
Olu Ojo ${ }^{\mathrm{a}}$
}

${ }^{a}$ Department of Business Administration, College of Management and Social Sciences, Osun State University, P. M. B. 2008, Okuku Osun State, Nigeria

\section{A R T I C L E I N F O}

\section{Article history:}

Received January 242010

Received in revised form

15 March 2011

Accepted 24 March 2011

Available online

25 March 2011

Keywords:

Diversification

Performance

Business organizations

Banking industry

Nigeria

\begin{abstract}
A B S T R A C T
This research investigates the diversification-performance relationship in Nigerian banking industry. Empirical evidences emerging from previous studies from developed countries about the effect of diversification on performance in the banking industry have so far yielded mixed results. There is a major gap in the relevant literature on developing countries which this research filled by studying Nigerian banks and providing empirical evidence on diversificationperformance relationship. Survey research design was adopted with the application of probability sampling technique in selecting our case study companies and respondents. Primary data were collected through questionnaire while secondary data were garnered from the annual report and accounts of the banks under study. Data were analyzed through descriptive statistics while correlation and ANOVA were used to test our hypotheses. It was discovered that diversification impacts corporate performance of these banks positively and recommends that these banks should engage in geographical diversification in addition to other forms of diversification they are currently involved in for maximum performance.
\end{abstract}

(C) 2011 Growing Science Ltd. All rights reserved.

\section{Introduction}

Development arising from environmental forces and the need for organizations to survive in today's fiercely competitive market are causing many organizations to rethink the way they are doing business in order to remain relevant to their stakeholders in the unfolding dispensations. These contextual influences not only present organizations with critical challenges, they also present new opportunities for growth and development. Companies are adopting various strategies to respond to these forces in order to survive and grow.

In the light of these new challenges, many organizations have played out the logical restructuring paths through the adoption of various performance improvement methodologies, which includes: corporate restructuring (CR), business process reengineering (BPR), organization development (OD), business process management (BPM), management by objective (MBO), management by exception (MBE), management by competitive edge (MCE), management by decision models (MDM), benchmarking, total quality management (TQM), mergers and acquisitions (M\&A) and others.

Despite the adoption and implementation of these strategic recipes in the past, organizations still find themselves in need of reinvigoration by way of strategic shifting of the organization structure from

\footnotetext{
* Corresponding author. Tel: +2348034943925

E-mail addresses: oluojoe@yahoo.com (O. Ojo) 
what it is now to what it has to be, in order to maintain competitive edge and satisfy customers needs at a profit. The desire for this repositioning has prompted many Nigerian banks to adopt diversification as corporate strategy. Thus, the focus of this research is to assess diversificationperformance relationship in selected Nigerian banks.

Academic interest in the topic of diversification is evident by the level of attention it has received over the last few decades. The relationship between corporate diversification and firm performance has been the subject of abundant research in several fields, including strategic management, industrial organizations, and corporate finance (Berger \& Ofek, 1995; Palich et al., 2000). While this topic is rich in studies, many researchers concurred on the fact that there is no agreement on the precise nature of the relationship between diversification and performance (Hoskisson \& Hitt 1990; Markides \& Williamson, 1994; Palich et al., 2000). Some studies have shown that diversification improves profitability over time (Chang \& Thomas, 1989; Lubatkin \& Rogers, 1989) whereas others have demonstrated that diversification decreases performance (Michel \& Shaked, 1984). Still other studies have shown that the diversification-performance link depends on business cycles (Hill, 1985). Santalo and Becerra (2004) explain conceptually and provide empirical evidence that no relationship (positive, negative or even quadratic) exists between diversification and performance.

Despite the plethora of studies on diversification in the last few decades, there is no widely accepted causal relationship between diversification and performance. The empirical evidences emerging from various studies about the effect of diversification on performance have so far yielded mixed results that are inconclusive and contradictory. Because of these contradictory results (Ramanujam \& Varadarajan, 1989), the relationship between diversification and performance is controversial. Thus, the question of whether diversification improves or worsens, firm performance is still worthy of further research such as the one being undertaken in this study. In addition, despite the existence of these studies, very little attention has been given to the banking industry. Besides, the impact of corporate diversification on firm performance in the banking industry has not received adequate research attention in Nigeria. Research also shows that most of the reported studies on the relationship between diversification and performance in the banking industry were carried out in industrialized countries such as the United States of America (Berger \& DeYoung, 2001; Stiroh \& Rumble, 2003), Britain (Dahl and Logan, 2003), Italy (Acharya et al., 2006) and Germany (Hayden et al., 2006) to mention a few. This means that there is a major gap in the relevant literature on developing countries including Nigeria, which has to be covered by research. This research attempts to fill this gap by studying the situation of the Nigerian banking industry and providing more empirical evidence on the effects of diversification on banks performance based on individual banklevel data.

The primary purpose of this study is the systematic discovery of the relationship between corporate diversification and firm performance in selected Nigerian banks. The following research questions are employed to guide this study. (1) What are the diversification strategies employed by Nigerian banks? (2) What are the problems militating against the use of diversification strategies by Nigerian banks? (3) Does diversification have any impact on the performance of Nigerian banks? (4) What are the profitable diversification strategies which can be suggested for Nigerian banks?

The general objective of this study is to evaluate the existing relationship between corporate diversification and firm performance in selected Nigerian banks. The specific objectives of the study are to: (1) Investigate the diversification strategies employed by Nigerian banking industry. (2) Examine the problems militating against the use of diversification by Nigerian banking industry. (3) Assess the impact of diversification on performance of Nigerian banking industry, and (4) Formulate profitable diversification strategies for Nigerian banks.

In order to answer the research questions and to achieve the objectives of the study, the following hypotheses are advanced and tested in the course of this study.

Hypothesis 1: $\boldsymbol{H}_{1}$ : There is a significant relationship between corporate performance and the degree of diversification practiced by Nigerian banks.

Hypothesis 2: $\boldsymbol{H}_{1}$ : There is a significant relationship between the level of success attained by the banks under study and the type of diversification strategy adopted. 


\section{Literature review}

\subsection{Conceptual framework}

The concept of diversification is yet to be clearly defined and there is no consensus on its precise definition among researchers. Definitions of diversification are many. What is needed, therefore, is a comprehensive definition, which is both theoretically valid and managerially meaningful.

Reed and Luffman (1986) pointed out that the term "diversification" has different meanings when research interest varied. Earlier definitions of diversification, such as Gort (1962) and Berry (1975), approached the subject from products or services across industry or market boundaries. Later definition extended to the means, particularly investment or partnership that enables a focal organization to achieve growth or reduce overall risk (Hoskisson \& Hitt 1990; Remanunam \& Varadarajan 1989). Diversification was frequently deployed as an important grand strategy for firm growth (Ansoff, 1965; Reed \& Luffman, 1986). While non-diversified firms take the advantage of the economies of scale, firms adopting a diversification strategy enjoy the economies of scope and the synergy is created by sharing strategic resources among business units (Hoskisson \& Hitt, 1990; Montgomery 1994; Ramanujam \& Varadarajan, 1989).

In general, diversification refers to a firm's entry into a new market. It means increase in the types of business a firm operates. That is diversification relates to products, geographical markets or knowledge (Penrose, 1995). The grand strategy involving diversification represent distinctive departure from the firm's existing base of operations, basically from acquisition and internal generation (spin-off) of a separate business with possibilities counter balancing the strengths and weaknesses of the two business. However, diversifications occasionally are undertaken as unrelated investments, because of the high profit potential and their minimal resource demands (St. John \& Harrison, 1999). Diversification can help reduce portfolio risk by eliminating non-systematic risk for which investors are not rewarded. Investors are rewarded for taking market risk. Because diversification averages the returns of the assets within the portfolio, it attenuates the potential highs (and lows). Diversification among companies, industries and asset classes affords the investor the greatest protection against business risk, financial risk and volatility.

\subsection{Motives for diversification}

There are many possible motives behind diversification strategies (Jung, 2003) and due to the nature of this research problems, the researcher intends to discuss the motives related to competitiveness and performance.

Synergistic motive: The first and obvious motive is shown in cases where synergy exists within individual units, which are operated as a single organization. Synergy occurs when the sum of all businesses together equals more than the sum of different units. Hitt et al. (2001), Amit and Livnat ( 1988) argue that diversification into related businesses may augment the market power of the diversified company which, in turn, may help the company enhance its long-term strategic position.

Financial motive: This motive is based on the fundamental premise of portfolio theory that "one should not put all one's eggs in one basket". It may also said that a firm should diversify and not depend on a single operation. As shown in finance theory, whenever the cash flows of the individual units are not perfectly correlated, the total risk, as measured by variability of consolidated cash flows, is reduced by diversification (Amit \& Livnat, 1988).

The market power motive: Conventional wisdom suggests that the bigger the company the more resources it controls, hence it should perform above average in an industry. Diversified firms have conglomerate power, which helps them thrive on their diversity (Hill, 1985). In his own view, Gribbin (1976) says a firm will not have conglomerate power if it does not hold significant positions in a number of markets.

4. The agency motive: A number of diversification motives from agency perspective will not be beneficial to the principal. The reason for this is the separation between the owner and manager, where the manager does not own any equity. This is in agreement with Sambharya's (2000) motive 
for diversification that it may reflect top management aspirations and goals. Four main reasons for managers to diversify the company are: (i) Empire building, which is a situation in which managers diversify in order to create their own empire (Montgomery, 1994). (ii) Managerial entrenchment, managers will diversify into markets or products in a way that increases the demand for their skills and abilities (Schleifer \& Vishny, 1989). (iii) Risk reduction, managers try to reduce their employment risk by diversifying into different markets and products and thereby make the organization less dependent on a single market or product. The basis of portfolio theory states that a firm should not put all her egg in one basket (Amit \& Livnat, 1988). (iv) Free cash flow theory, instead of paying stake owners the managers spend the excess cash flow on acquisitions (Jensen, 1986). The reason for this is that in the beginning of the firms life cycle there are lot of profitable opportunities for reinvestments, however, when the firm becomes mature these opportunities become more scarce and hence the cash flow from earlier innovations are being used for opportunistic diversification (Mueler, 1972).

5. The resource motive: Conventional wisdom suggests that the bigger the company the more resources it controls, hence it should perform above average in an industry. This wisdom is the resource- based motive, which states that bundled resources and capabilities that are aggregated over time also underpin a company's competitive advantage (Barney, 1991). When a firm has underused resources that can be profitably employed, it also has an incentive to expand. Furthermore, diversification is driven by the need to use these excess resources (Caves, 1981). In order to grow, the firm needs to specialize and the resources from the successful growth will be used to diversify the company.

\subsection{Diversification strategies}

There are three general types of diversification strategies discussed in the literature: a) growth into a new non-competing product/market which is related to the firm's technological and marketing skills based on termed related or concentric diversification; b) growth into a new product that will appeal to current customers often called horizontal diversification; and c) growth into a new product/market which is unrelated to the firm's present technological or marketing skills commonly called conglomerate diversification. Each of these diversification strategies has its own set of issues, benefits, and drawbacks.

\subsection{The benefits and costs of corporate diversification}

There are both benefits and costs associated with corporate diversification. The efficient internal capital market argument typically suggests that diversified firms have more access to internally generated resources and can exploit superior information to allocate resources among divisions (Williamson, 1967). Diversified firms can also employ a number of mechanisms to create and exploit market power advantages, tools that are largely unavailable to their more focused counterparts. These include predatory pricing. Predatory pricing is defined as sustained price cutting with the aim of preventing existing rivals from future entry. Others are cross-subsidization in which the firm taps excess revenues from one product line to support another. Entry deterrence is a method of constructing a reputation for predatory behavior to prevent a new entry. Finally, reciprocal buying and selling in which the focal company gives preference in purchasing decisions or contracting requirements to suppliers. From a resource-based perspective further benefits of diversification include the ability to exploit excess firm specific assets and share resources such as brand names, managerial skills, consumer loyalty and technological innovations.

Benefits also stem from tax and other financial advantages associated with diversification (Berger \& Ofek, 1995), and increased debt capacity due to reduced bankruptcy probabilities (Lewellen, 1971). Majd and Meyers (1987) for instance, note that undiversified firms are at a significant tax disadvantage because tax is paid to the government when income is positive, but the government does not pay the firm when income is negative. This disadvantage is reduced, but not eliminated, by the tax code's "carry back" and "carry forward" provisions. Their analysis predicts that as long as one or 
more segments of conglomerate experience losses in some years, a conglomerate pays less in taxes than what separate units could do.

Diversifying activities of a firm can also be associated with several disadvantages. The predominant view is that diversified firms are engulfed with severe agency problems that lead to inefficient resource allocation. Jensen (1986) asserts that managers of firms with unused borrowing power and large free cash flows are more likely to undertake unnecessary expansion activities for their private benefits. Many studies document empirical support for the agency explanation (e.g. Jiraporn et al., 2006). Williamson (1967) stresses the information processing problems that arise between corporate headquarters and divisional managers. Information and incentive problems also lead to misallocation of resources among divisions of a diversified firm (Meyer et al., 1992; Rajan et al., 2000).

Furthermore, Santaló and Becerra (2006) state that the diversification-performance relationship depends on the relative efficiency of diversifying firms and industry characteristics. Because of these myriad benefits and costs, it is difficult to predict a priori the net impact of benefits and costs associated with corporate diversification on firm performance.

\subsection{Theoretical framework}

\subsubsection{The Linear Model}

Beginning with Gort (1962), industrial organization economics spawned decades of research based on the premise that diversification and performance are linearly and positively related. This position rest upon several assumptions, including those derived from market power theory and internal market efficiency arguments, among others (Grant, 1998).

Integrating the argument outlined above, a linear and positive linkage is suggested and presentations of theory continue to mention these arguments as part of diversification-performance puzzle. However, does the evidence support this position? In the recent review of relevant research, Denis et al. (1997) conclude that empirical evidence suggests the cost of high level of diversification outweigh the benefits, that focused firm perform more than their diversified counterparts. However, it should be noted that these findings are not universal across or within studies (Servaes, 1996). These inconsistencies have lead to researchers using alternative models, particularly those that are curvilinear in orientation.

\subsubsection{Curvilinear models}

In contrast to the argument presented above, a number of researchers have developed theory positing a curvilinear diversification-performance relationship. This theory recognizes that increasing diversification may not be associated with concomitant increases in performance, at least not through the entire relevant continuum. Two alternatives have surfaced in the literature; the Inverted-U Model and the Intermediate Model. Each of these posits that some diversification (i.e., moderate level or related diversification) is better than none; however they differ in their predictions of the performance trend as firm move toward even greater (usually unrelated) diversification. These curvilinear models are presented below.

(a) The Inverted-U Model: Limited diversification presents a strategy of restricted business where the firm focuses on a single industry, thus limiting opportunities to leverage resources and capabilities across divisions. The argument outlined above (i.e. linear model) indicates that limited diversifiers as a group are unlikely to generate above average profits. Lubatkin \& Chatterjee (1994) observe that single business firm do not have the opportunity to exploit between unit synergies or the portfolio effect that are available only to moderately and highly diversified firms. That is, focused enterprises do not have multiple businesses, so they do not enjoy scope economics. This means that these firms bear greater risk since they have not "diversified away" that risk by combining less than perfectly correlated financial streams from multiple businesses. This has negative implication for the debt capacity, cost of capital, and market performance of single business entities (Shleifer \& Vishny, 1991). 
(b) The Intermediate Model: Few people have questioned the superiority of related over limited diversification. However, the relative performance contribution of related versus unrelated diversification is often debated. It may be that related and unrelated diversification is somewhat equal in their contribution to performance. The primary issue in this controversy arises from concerns that related firms may not be able to exploit fully the relatedness designed into the portfolio business. It was argued that related diversifiers will outperform their unrelated counterparts only to the degree that they are able to exploit relatedness "to create and accumulate new strategic assets more quickly and cheaply than competitors" (Markides \& Williamson, 1994). Simply amortizing existing assets through economies of scope will yield short-term benefits at best.

In general, the Intermediate Model can be tied to the notion that diversification yields positive but diminishing returns beyond some point of optimization. Markides (1992) provides a helpful review of the argument supporting this view. He stated that as a firm increases in diversification, it moves further away from its core business, and the benefit of diversification decline.

\subsection{Empirical studies on diversification and performance}

A large number of empirical studies have tried to hypothesized and test empirically the question of which type of company or diversification strategy has led to better performance. Such empirical studies came from different discipline such as industrial economics, strategic management, and finance. Rumelt $(1974,1982)$ propounds that related diversification will lead to superior levels of performance while unrelated diversification will recognize inferior levels of performance. On the empirical side, Salter and Weinhold (1979) note that "unrelated diversification does not lead to higher corporate returns". Other scholars such as Nathanson and Cassano (1982) say that diversity can hurt profits but appropriate organizational structures and strategies can help mitigate the damage, Gort (1962) also imputed that the premise that diversification and performance are linearly and positively related. Finally et al. (1994) also recognize the fact that increasing diversification may not be associated with concomitant increases in performance.

The empirical evidence on performance and diversification can be divided into three different groups:

(a) Related performs better than unrelated

(b) No differences between related and unrelated

(c) Unrelated outperforms related

Sambharya (2000) addresses that the contradictory results is related to: different time periods, various measures on profitability, and different measures on diversification.

\section{Material and methods}

This section deals with the specific procedures utilized in the conduct of this study. The term research methodology is a system of explicit rules and procedures in which this research is based and against which claims of knowledge are evaluated (Ojo, 2003). Therefore, this section focuses on the research techniques adopted and used for this study with the aim of achieving the research objectives. For the purpose of this study, survey research design is adopted. The research design chosen is perceived as a good method because it helps identify changes in corporate performance due to diversification. The theoretical population of the study consisted of the entire commercial banks operating in the South Western Nigeria. This choice stems from the fact that the Headquarter Offices of these companies were located in this region of the country. For effective coverage and lower cost, this study was restricted to Lagos State, the commercial centre of Nigeria. Primary method of data collection was used in the study. The close-ended questions were used in order to simplify the coding and analytical procedure. The questionnaire is titled "Strategic Corporate Diversification and Performance Relationship Questionnaire.”

To ensure the validity and reliability of the questionnaire used for the study, even number of experts were consulted to look at the questionnaire items in relation to its ability to achieve the stated objectives of the research, level of coverage, comprehensibility, logicality and suitability for prospective respondents. 
Data collected from the questionnaire are analyzed with the aid of descriptive statistical techniques such as total score, and percentage while inferential statistics such as correlation coefficients are used to prove the level of significance in testing stated hypotheses.

\section{Results}

At this juncture, it is important to test the validity or otherwise of the hypotheses postulated with the available data, which are analyzed and the information gathered in this study. Two hypotheses are formulated to guide this study. Each hypothesis was, however, tested separately to determine its relevance in the light of the available evidence from both the primary and the secondary data analyzed in this study. Hypothesis 1 is tested by correlation while hypothesis 2 is tested by analysis of variance.

\section{Hypothesis 1}

H1: There is a significant relationship between corporate performance and the degree of diversification practiced by Nigerian banks.

\section{Table 1}

Correlations

\begin{tabular}{|c|c|c|c|c|}
\hline & & ownership structure & market power & Synergistic motives \\
\hline \multirow[t]{3}{*}{ ownership structure } & Pearson Correlation & 1 & $.176(* *)$ & $.139(*)$ \\
\hline & Sig. (2-tailed) & & .005 & .028 \\
\hline & $\mathrm{N}$ & 250 & 250 & 250 \\
\hline \multirow[t]{3}{*}{ market power } & Pearson Correlation & $.176(* *)$ & 1 & \\
\hline & Sig. (2-tailed) & .005 & & \\
\hline & $\mathrm{N}$ & 250 & 250 & \\
\hline \multirow[t]{3}{*}{ Synergistic motive } & Pearson Correlation & $.139(*)$ & & 1 \\
\hline & Sig. (2-tailed) & .028 & & \\
\hline & & 250 & 250 & \\
\hline
\end{tabular}

** Correlation is significant at the 0.01 level (2-tailed).

The above correlation table clearly revealed that there is a significant relationship between diversification and performance. This is evidenced from the various Pearson correlations confident that is at 2-tailled 0.01 and 0.05 significant level. We therefore reject our null hypothesis 1 (Ho) and accept our alternative hypothesis 1 (H1).

\section{Hypothesis 2}

H1: There is significant relationship between the level of success attained by the banks under study and the type of diversification strategy adopted.

Table 2

Diversification strategies, profit before tax

\begin{tabular}{lllllcccc}
\hline & & \multicolumn{7}{c}{$95 \%$ Confidence interval for Mean } \\
\hline & $\mathrm{N}$ & Mean & $\begin{array}{l}\text { Std. } \\
\text { Deviation }\end{array}$ & $\begin{array}{l}\text { Std. } \\
\text { Error }\end{array}$ & $\begin{array}{l}\text { Lower } \\
\text { bound }\end{array}$ & Upper bound & Minimum & Maximum \\
\hline 1 & 32 & 1.97 & .822 & .145 & 1.67 & 2.27 & 1 & 3 \\
2 & 35 & 1.74 & .741 & .125 & 1.49 & 2.00 & 1 & 3 \\
3 & 49 & 1.71 & .791 & .113 & 1.49 & 1.94 & 1 & 3 \\
4 & 60 & 1.73 & .800 & .103 & 1.53 & 1.94 & 1 & 3 \\
5 & 74 & 1.78 & .781 & .091 & 1.60 & 1.96 & 1 & 3 \\
\hline Total & 250 & 1.78 & .785 & .050 & 1.68 & 1.87 & 1 & 3 \\
\hline
\end{tabular}


Table 3

Test of homogeneity of variances: Profit before Tax

\begin{tabular}{llllll}
\hline Levene Statistic & $\mathrm{df1}$ & $\mathrm{df} 2$ & Sig. & & \\
\hline .242 & 4 & 245 & .914 & & Sig. \\
\hline ANOVA & Sum of Squares & $\mathrm{df}$ & Mean Square & F & .652 \\
\hline Between Groups & 1.528 & 4 & .382 & .616 & \\
Within Groups & 151.928 & 245 & .620 & & \\
\hline Total & 153.456 & 249 & & & \\
\hline
\end{tabular}

Table 4

Multiple comparisons of diversification strategies dependent variable: profit before tax Tukey HSD

\begin{tabular}{|c|c|c|c|c|c|c|c|}
\hline & & & & & & $95 \% \mathrm{C}$ & ce Interval \\
\hline $\begin{array}{l}\text { (I) } \\
\text { diversification }\end{array}$ & (J) diversification & $\begin{array}{l}\text { Mean } \\
(\mathrm{I}-\mathrm{J})\end{array}$ & Difference & Std. Error & Sig. & $\begin{array}{l}\text { Lower } \\
\text { bound }\end{array}$ & $\begin{array}{l}\text { Upper } \\
\text { bound }\end{array}$ \\
\hline \multirow{4}{*}{1} & 2 & .226 & & .193 & .767 & -.30 & .76 \\
\hline & 3 & .254 & & .179 & .614 & -.24 & .75 \\
\hline & 4 & .235 & & .172 & .650 & -.24 & .71 \\
\hline & 5 & .185 & & .167 & .801 & -.27 & .64 \\
\hline \multirow{4}{*}{2} & 1 & -.226 & & .193 & .767 & -.76 & .30 \\
\hline & 3 & .029 & & .174 & 1.000 & -.45 & .51 \\
\hline & 4 & .010 & & .167 & 1.000 & -.45 & .47 \\
\hline & 5 & -.041 & & .162 & .999 & -.48 & .40 \\
\hline \multirow{4}{*}{3} & 1 & -.254 & & .179 & .614 & -.75 & .24 \\
\hline & 2 & -.029 & & .174 & 1.000 & -.51 & .45 \\
\hline & 4 & -.019 & & .152 & 1.000 & -.44 & .40 \\
\hline & 5 & -.069 & & .145 & .989 & -.47 & .33 \\
\hline \multirow{4}{*}{4} & 1 & -.235 & & .172 & .650 & -.71 & .24 \\
\hline & 2 & -.010 & & .167 & 1.000 & -.47 & .45 \\
\hline & 3 & .019 & & .152 & 1.000 & -.40 & .44 \\
\hline & 5 & .050 & & .137 & .996 & -.43 & .33 \\
\hline \multirow{4}{*}{5} & 1 & -.185 & & .167 & .801 & -.64 & .27 \\
\hline & 2 & .041 & & .162 & .999 & -.40 & .48 \\
\hline & 3 & .69 & & .145 & .989 & -.33 & .47 \\
\hline & 4 & .050 & & .137 & .996 & -.33 & .43 \\
\hline
\end{tabular}

From Table 2, we have presented various analysis of diversification strategies employed by the different banks. The outcome of multiple comparisons of them reveals powerful positive relationship between diversification strategies and performance of the study companies. We therefore reject our alternative hypothesis and accept our null hypothesis.

Table 5

Diversification strategies of various banks, profit before Tax, Tukey HSD

\begin{tabular}{lll}
\hline & $\mathrm{N}$ & Subset for alpha $=.05$ \\
\hline Diversification Strategies & 1 & 1 \\
\hline 3: Conglomerate Strategy & 49 & 1.71 \\
4: Product Strategy & 60 & 1.73 \\
2: Horizontal Strategy & 35 & 1.74 \\
5: Geographic Strategy & 74 & 1.78 \\
1: Concentric Strategy & 32 & 1.97 \\
\hline Sig. & & .539 \\
\hline
\end{tabular}


Means for groups in homogeneous subsets are displayed.

a Uses Harmonic Mean Sample Size $=45.286$.

b The group sizes are unequal. The harmonic mean of the group sizes is used. Type I error levels are not guaranteed.

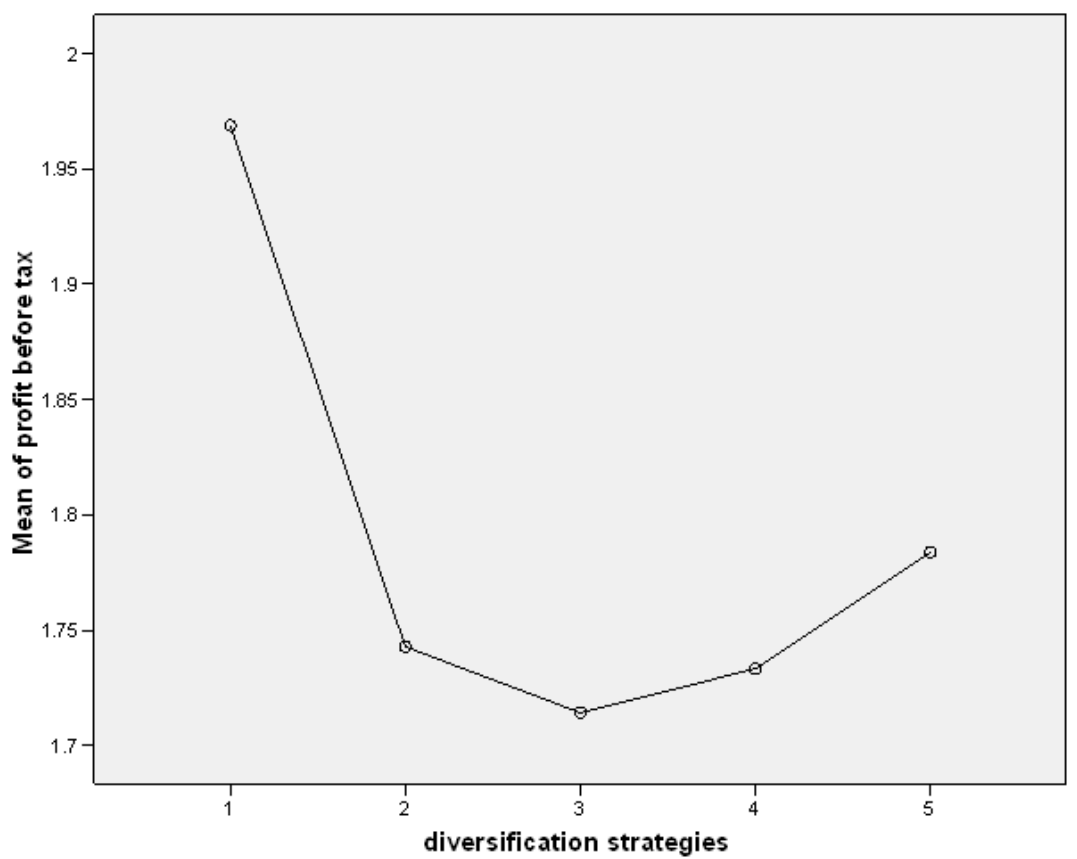

Fig. 1. Mean plot graph

From data analysis of this research study, it is discovered that majority of respondents said that their banks were involved in geographic diversification more than any other type of diversification. However, evidence from the above mean plot graph revealed that on the average concentric diversification strategy yields more profit than any other form of diversification strategies while conglomerate form of diversification yields the least mean profit after tax. Based on these findings, it means that there is no significant relationship between corporate performance attained by Nigerian banks and the type of diversification strategy adopted. Thus, we reject our alternative hypothesis and accept our null hypothesis.

\section{Discussion of results}

The main results that emerged from this study are as follows:

1. The study found that the deliberate practice of diversification by Nigerian banks is becoming widely accepted. This is probably in recognition of the threat to corporate survival posed by rapid changes and the increasing complexity and uncertainty of the corporate operating environment and the need to match and maintain a healthy balance with the opportunities and threat that are emerging from them.

2. In spite of the recognition of the importance of diversification, the use of this approach is still low and rudimentary in some banks. However, the spread in the practice of diversification is expected to increase as the dynamics in the environment continue to exert a greater pressure on banking activities and prospects. It is also expected to increase as more banks become aware of the benefits of diversification strategic emphasis particularly as a means of improving and channeling of efforts towards the attainment of organizational objectives.

3. A positive relationship was found between the age, ownership structure, resource motives, financial power, profit before tax, total assets, total deposits, synergistic motive and the level of diversification that is practiced by the banks. The relationship was found to be strong and statistically significant. 
4. The researcher also found that a number of problems have militated against the practice of diversification strategies by Nigerian banks. Such problems are ineffective communication, resentment and resistance to change within the firm. Next is failure to determine the focus of diversification, inability to define and analyze their competitive positions properly, poor execution and management of diversification strategy among others.

5. The banks under study has adapted a number of diversification strategies at varying degrees. These are geographic diversification $29.6 \%$, concentric diversification $13.6 \%$, horizontal diversification $13.6 \%$, conglomerate diversification $18.8 \%$, and product diversification $24.4 \%$. However, there is little significant relationship between corporate performance and diversification strategies employed by Nigerian banks.

\section{Recommendations}

In the light of the study, the data analyzed and the research problems highlighted concerning the relationship between diversification and performance, the following recommendations are hereby made for Nigerian banks to succeed in their diversification projects.

1. The banks should raise the level of diversification that is practiced by them. This could be done by involving in a number of diversification strategies that will position the banks realistically within their environments. This organized action will also enable the banks to build strong identities and to make the best use of their strengths all of which will influenced their performance positively.

2. As shown in our introduction, a major characteristic of the corporate external environment is its propensity towards change. The changes in environments are not only rapid and bewildering; they also appear to be in a state of constant flux. For this reason, the banks cannot afford to stand still while the world around them is drastically and continually altered. Dynamic management teams which will select optimal diversification strategies and monitor their execution and reward progress toward their achievement and remain flexible in altering corporate direction is the best way to enable the banks to anticipate and adapt to changes.

3. The organizational structure of the banks should provide an environment in which top management can develop appropriate attention to diversification strategy unencumbered by operating demands. This structure can be created by delegating much of the decision making authority to lower management staff such as middle level and lower level managers. Therefore, for effective realization of the impact of diversification on firm performance, all categories of staff should be involved in diversification strategy of their organization at one point or another. In order to achieve this laudable goal, employees should be trained and developed to acquire the skills and attitudes required to implement diversification strategy.

4. In addition to staff training and development program, it is advisable that each bank should have a diversification strategy program consultant as a design resource, technical adviser, coach, and facilitator thus contributing to both staff support and in-house capacity building.

5. More than anything else, open and honest communication is imperative. Firms must make employees feel respected, valued, and indispensable for the implementation of diversification strategy of the organization. Employees must feel that they are being informed accurately and in a timely fashion. Confidential financial and competitive information must be shared with employees in order to enhance their level of trust, encourage them to cooperate and to help the firm in its diversification strategic drive.

6. When employing staff for the organization, the company should employ well qualified and dedicated employees who hope to input their educational and technical knowhow for the effective and efficient management of the business of the organization, so as to help in minimizing cost and increasing the profit of the organization.

\section{Conclusion}

The prudent management of diversification is very important in any business as it is said to enhance the wellbeing of the business and its effective and efficient management will contribute to sound 
performance and profitability of the business. The Nigerian banks should therefore give a greater priority to the management, enhancement and financing of diversification.

Various reasons, models and explanation have been given in this research to enlighten individuals about the positive impact of diversification on the organization's performance and the reason why Nigerian managers should welcome diversification in their business and avail them of the prevailing benefits of adopting diversification. Therefore, the need to embrace diversification is glaring for Nigerian manager and the need to see diversification has a corporate performance enhancer is important.

\section{References}

Acharya, V., Hasan, I. \& Saunders, A. (2006). Should Banks be Diversified? Evidence from Individual Bank Loan Portfolios. Journal of Business 79(3), 1355-1413.

Amit, R. \& Livnat, J. (1988). Diversification and the Risk-Return Trade-off. Academy of Management Journal, 31, 154-166.

Ansoff, H. I. (1965). Corporate Strategy: An Analytic Approach to Business Policy for Growth and Expansion., New York: McGraw-Hill.

Barrney, J. B. (1991). Firm resources and sustainable competitive advantage. Journal of Management, 17(1), 99-120.

Berger, P. G. \& Ofek, E. (1995). Diversification's effect on firm value. Journal of Financial Economics, 37, 39-65.

Berger, A. \& DeYoung, R. (2001). The effects of geographic expansion on bank efficiency. Journal of Financial Services Research 19(2/3), 163-185.

Berry, C.H. (1975). Corporate growth and diversification. Princeton: Princeton University Press.

Caves, R. E. (1981). Diversification and seller concentration: Evidence from Change 1963-1972. Review of Economics and Statistics, 63, 289-293.

Chang,Y \& Thomas, H. (1989). The impact of diversification strategy on risk return performance. Strategic Management Journal 10(3), 271-284.

Dahl, D., \& Logan, L. (2003). Granularity and International Diversification: An Empirical Analysis of Overdue Claims at Bank. Mimeo, Bank of England.

Denis, D. J., Denis, D. K., \& Sarin, A. (1997). Agency problems, equity ownership, and corporate diversification. Journal of Finance, 52, 135-160.

Grant, R. M. (1998). Contemporary Strategy Analysis. Oxford: Blackwell.

Gort, M. (1962). Diversification and integration in American industry. Princeton: Princeton University Press.

Gribbin, J. (1976). The Conglomerate Merger. Applied Economics, 8.

Hayden, E., Porath, D. \& Westernhagen, N. (2006). Does diversification improve the performance of German banks? evidence from individual bank loan portfolios. Banking and Financial Studies, 5(2), Deutsche Bundesbank.

Hill, C. W. L. (1985). Diversified growth and competition: The experience of twelve large UK firms. Applied Economics 17, 827-847.

Hitt, M., Ireland, R. \& Hoskisson, R. (2001). Strategic management: competitiveness and globalisation, Cincinnati: South-Western College Publishing.

Hoskisson, R. E., \& Hitt, M. A. (1990). Antecedents and performance outcomes of diversification: review and critique of theoretical perspectives. Journal of Management 16, 461-509.

Jensen, M. C. (1986). Agency costs of free cash flow, corporate finance, and takeovers. American Economic Review , 76, 323-329.

Jiraporn, P., Kim, Y., Davidson, W. \& Singh, M. (2006). Corporate Governance, Shareholder rights and firm diversification: An empirical analysis. Journal of Banking \& Finance, 30, 947-963.

Jung, J. (2003). The bigger, the better? Measuring the financial health of media firms. The International Journal on Media Management, 5(4), 237-250.

Lewellen, W. (1971). A pure financial rationale for the conglomerate merger. Journal of Finance 26, 521-537. 
Lubatkin, M., \& Rogers, R. C. (1989). The impact of diversification strategy on risk return performance. Strategic Management Journal, 10, 271-284.

Lubatkin, M. H., \& Chatterjee, S. (1994). Extending modern portfolio the domain of corporate diversification: does it apply? Academy of Management Journal, 37, 109-136.

Majd, S., \& Meyers, S. (1987). Tax asymmetries and corporate income tax reform. Effects of Taxation on Capital Accumulation. Ed. M. Fedstein. Chicago: University of Chicago Press.

Markides, C. C. (1992). Consequences of corporate refocusing: Ex ante Evidence. Academy of Management Journal, 35, 398-412.

Markides, C. C., \& Williamson, P. J. (1994). Related diversification, core competencies and corporate performance. Strategic Management Journal, 15, 149-165.

Meyer, M., Milgrom, P. \& Roberts, J. (1992). Organizational prospects, influence costs and ownership changes. Journal of Economics and Management Strategy, 1, 9-35.

Michel, A., \& Shaked, I. (1984). Does business diversification affect performance? Financial Management, 13(4), 18-25.

Montgonmery, C. A. (1994). Corporate diversification. Journal of Economic Perspectives, 8, 163-178.

Mueller, D. (1972). A life cycle theory of the firm. Journal of Industrial Economics, 20, 199.

Nathanson, D. A., \& Cassano, J. S. (1982). Organization, Diversity, and Performance. Wharton Magazine 6, 19-26.

Ojo, O. (2003). Fundamentals of Research Methods. Lagos: Standard Publications.

Palich, L., Cardinal, L. \& Miller, C. (2000). Curvilinearity in the diversification-performance linkage: An examination of over three decades of research. Strategic Management Journal, 21, 155-174.

Penrose, E. (1995). The Theory of the Growth of the Firm. Oxford: Oxford University Press.

Rajan, R., Servaes, H. \& Zingales, L. (2000). The cost of diversity: diversification discount and inefficient investment. Journal of Finance, 55, 35-80.

Ramanujam, V., \& Varadarajan, P. (1989). research on corporate diversification: A synthesis. Strategic Management Journal, 10(6), 523-551.

Reed, R., \& Luffman, G. A. (1986). Diversification: the growing confusion. Strategic Management Journal, 7, 29-35.

Rumelt, R. P. (1974). Strategy, structure, and economic performance. Cambridge: Harvard University Press.

Rumelt, R. P. (1982). Diversification strategy and profitability. Strategic Management Journal 3(4), 359-369.

Salter, M. S., \& Weinhold, W. S. (1979). Diversification through acquisition. New York: The Free Press.

Sambharya, R. B. (2000). Assessing the construct validity of strategic and SIC-based measures of corporate diversification. British Journal of Management 11, 163-173.

Santalo, J. \& Becerra, M. (2006). The dominance of diversified versus specialized firms across industries, Journal of Business Research, 59: 335-340.

Santalo, J., \& Becerra, M. (2004). The effect of diversification on performance revisited: diversification discount, premium, or both? Institutode de Empresa, Working Paper, Madrid.

Schleifer, A. \& Vishny, R. W. (1991). Takeovers in the '60s and the '80s: evidence and implications, Strategic Management Journal, 12: 51-59.

Schleifer, A., \& Vishny, R. W. (1989). Management Entrenchment: The case of manager-specific investments. Journal of Financial Economics, 25, 123.

Servaes, H. (1996). The value of diversification during the conglomerate merger wave. Journal of Finance, 51, 1201-1225.

St. John C. H., \& Harrison, J. S. (1999). Manufacturing-based relatedness, synergy, and coordination. Strategic Management Journal, 20, 129-145.

Stiroh, K., \& Rumble, A. (2003). The dark side of diversification for U. S. bank holding companies. Unpublished Paper, Federal Reserve Bank of New York.

Williamson, O. (1967). Hierarchical control and optimum firm size. Journal of Political Economy 75, 123-138. 